\title{
Jumbled Lyric Cards: A Listening Activity as a Learning Alternative Used to Spend School Holiday
}

\author{
Lilik Tri Mulyani \\ State University of Surabaya \\ Surabaya, Indonesia \\ $\underline{\text { liliktrie.lt@gmail.com }}$
}

\begin{abstract}
Holiday is the time for learner to be free from a long school learning process and the hard test. In fact, the learner spends most of the time to play, watch TV etc. In this point, time should be used to increase the learner's capability before going to the next learning level. Based on the problem above, the researcher is interested in discovering the learning alternative to be done in a school holiday. It is an arranging jumbled lyrics card as an English listening activity. It deals with the jumbled lyric card, arranged, and discussion. The participant is a girl, graduated from the Junior high school and waits for her new learning on the Senior High School, learn in one of English course in Mojoagung, Jombang. This is a qualitative research which deals with the brief description about the learner's listening activity done in school holiday. The data was taken from the learner's activity in each meeting. There were 10 meetings observed. The researcher analyzed her progress and also gave her questions deals with the activity. The result of the research shows that by arranging jumbled lyrics card, the learner has progress on her listening capability, feels happy with the activity, has higher motivation on English learning, enjoys her learning on the school holiday and makes it meaningful. Finally, the researcher hopes that this research gives big contribution in giving new English teaching and learning innovation in Indonesia.
\end{abstract}

Keywords-jumbled lyric cards; listening activity; qualitative research; English course

\section{INTRODUCTION}

For Indonesian learners, holiday is time to be free from the long school learning process and its hard test. In fact, the learners spend most of the time to play games, watch TV and even go somewhere with their family. A survey conducted by Warbutons, (reported by www.detik.com on Tuesday, August $13^{\text {th }}$ 2013) stated that 9 from 10 children felt bored in their holiday so they choose to play gadget. This activity makes them to be passive. It is very different with the school time where they think hard and have physical exercise. To fill the gap between the active activity in school day and the passive one in holiday, there should be an activity which covers a learning activity in the holiday.

English can be learnt by many activities and ways. Joyful learning is important to attract the learners in order to have high motivation. One of them is through listening song. Based on the curriculum 2013, listening to the song include into the standard competence for the $3^{\text {rd }}$ level of Senior High School in the second semester. In listening class, there are many implemented activities. Mostly, the learners are instructed to fill the cloze test listening. Another alternative listening activity is through arranging the jumbled lyrics. It is a modification learning activity between reading and listening skills. In this learning alternative, there are many points to be learnt, such as the pronunciation, speaking, writing, the social function, and also cultural aspects of the song. Based on the description above, the researcher is interested in discussing the jumbled lyric cards, limiting in a listening activity as a learning alternative used to spend school holiday.

\section{LITERATURE REVIEW}

\section{A. Listening}

First, Listening is important since it is one of a receptive skill. But, mostly it is not emphasized in teaching and learning process because it is the part of speaking [1]. Further he stated that there are 4 listening performances; intensive, responsive, selective, extensive. Intensive performance deals with perception of language components, responsive listening deals with the short strech of language to make a short response, selective is a listening performance focus on the process streches of discourse to "scan" for certain information, and the last is extensive which deals with the develop a top-down global understanding.

\section{B. Media}

Media are various components in learners' environment which support the learners learn. Media is also the physical means which are used to send messages to the students and stimulate them to learn. Both of the two experts stated that media is learning aids to help learner in teaching and learning process, include support, motivate and also stimulate. The use of media is important for the following reasons [2]:

- Instructional media can be solved the lack of the learners' experiences. 
- Instructional media can be reached everything out of the class.

- Instructional media are created the possible direct interaction between the learners and their environment.

- Media are produced some observation.

- Media can be kept the basic, concrete and real concepts of the teaching.

- The learners' motivation is aroused by using media in learning.

- Media are integrated the experience from the concrete things to the abstract ones.

There are six kinds of media. One of them is audio recording. Recording is a mode of magnetic, on disc, or on motion picture soundtracks. This media is best used in listening. Another media mostly used in learning is card. This includes into the visual media. There are 3 main criteria of choosing the appropriate media. They are: practicality, student appropriateness, and instructional appropriateness. There are some considerations in choosing the song used in listening activity. Firstly, the language level and age of the students has to be taken into consideration when choosing songs for a lesson. Secondly, the language content and musical value of each song have to be the primary consideration in selecting songs. Thirdly, the speed of a song will also affect the choice.

Jumbled lyric card is a new media in listening activity. There are some cards which contain jumbled song lyrics. The learner is instructed to arrange them while the listening process. The way of scoring is through the best arrangement. For example; there are 20 cards, so the learner has to arrange them to good order based on the song. If there are 5 points in order, there are 15 right answers, it is divided by the whole lyrics (20) times $100 \%$. The $75 \%$ represents the learner's listening capability.

\section{METHOD}

This is a descriptive qualitative research. Qualitative research investigates the quality of relationships, activities, situations, and materials. It focuses on understanding the context and attempts to explain the intentionality of behaviors[3]. It gives brief description of the phenomena. This research focuses on the listening activity that done in the holiday. There is one participant, named Novi Ardiana, 15 years old. She is a student graduated from one of State Junior High School in Mojoagung (SMPN 1 Mojoagung, Jombang). While waiting for her next study in Senior High School, she joins an English course named ELC (Eternal Learning Community) in MojoagungJombang.The data of the research are gotten from her daily listening activity in 10 meetings, observation and questionnaire' result as well. The way of collecting data are through conducting test, observation, and also giving questionnaire. In this point, the researcher observes her listening progress in 10 meetings of listening activity, give questionnaire to see her opinion about the listening program, and see her effort as the result of higher motivation in learning English.

\section{RESULT}

\section{A. Listening Progress}

There are 10 meetings observed. The learner listens to one song for each meeting which is chosen randomly as presented in TABLE I.

\begin{tabular}{|c|c|c|c|c|c|}
\hline \multirow{3}{*}{ Meetings } & \multicolumn{5}{|c|}{ Description } \\
\hline & \multirow[t]{2}{*}{ Songs } & \multirow{2}{*}{$\begin{array}{l}\text { Listening jumbled } \\
\text { lyric percentage } \\
\text { Points }\end{array}$} & \multirow{2}{*}{$\begin{array}{l}\text { Music } \\
\text { rhythm }\end{array}$} & \multicolumn{2}{|c|}{$\begin{array}{l}\text { Ever/ never } \\
\text { listens to }\end{array}$} \\
\hline & & & & Ever & Never \\
\hline $1^{\mathrm{st}}$ & $\begin{array}{c}\text { Hello } \\
\text { (Adelle) }\end{array}$ & $12 / 28 * 100 \%=42 \%$ & Beat & $\sqrt{ }$ & \\
\hline $2^{\text {nd }}$ & $\begin{array}{l}\text { Fight song } \\
\text { (Rachel } \\
\text { Platten) } \\
\end{array}$ & $13 / 33 * 100 \%=39 \%$ & Beat & & $\sqrt{ }$ \\
\hline $3^{\text {rd }}$ & $\begin{array}{c}\text { Firework } \\
\text { (Katy } \\
\text { Perry) } \\
\end{array}$ & $18 / 28 * 100 \%=64 \%$ & Beat & $\sqrt{ }$ & \\
\hline $4^{\text {th }}$ & $\begin{array}{l}\text { Hero } \\
\text { (Mariah } \\
\text { Carey) }\end{array}$ & $15 / 17 * 100 \%=88 \%$ & Slow & & $\sqrt{ }$ \\
\hline $5^{\text {th }}$ & $\begin{array}{l}\text { Faded } \\
\text { (Alan } \\
\text { Walker) }\end{array}$ & $11 / 11 * 100 \%=100 \%$ & Slow & $\sqrt{ }$ & \\
\hline $6^{\text {th }}$ & $\begin{array}{l}\text { You are my } \\
\text { life (Harris } \\
\mathrm{J} \text { ) }\end{array}$ & $15 / 15 * 100 \%=100 \%$ & Slow & $\sqrt{ }$ & \\
\hline $7^{\text {th }}$ & $\begin{array}{l}\text { So soon } \\
\text { (Maher } \\
\text { Zein) }\end{array}$ & $14 / 17 * 100 \%=82 \%$ & Slow & & $\sqrt{ }$ \\
\hline $8^{\text {th }}$ & $\begin{array}{l}\text { Right here } \\
\text { waiting } \\
\text { (Richard } \\
\text { Marx) }\end{array}$ & $10 / 12 * 100 \%=83 \%$ & Slow & $\sqrt{ }$ & \\
\hline $9^{\text {th }}$ & $\begin{array}{l}\text { I promise } \\
\text { (Harris J) }\end{array}$ & $18 / 18 * 100 \%=100 \%$ & Slow & $\sqrt{ }$ & \\
\hline $10^{\text {th }}$ & $\begin{array}{l}\text { My love } \\
\text { (Westlife) }\end{array}$ & $14 / 14 * 100 \%=100 \%$ & Beat & & $\sqrt{ }$ \\
\hline
\end{tabular}

Based on the table, there is a progress in her listening result. It is seen from the $1^{\text {st }}$ meeting ( $42 \%$ points) up to the $10^{\text {th }}$ meeting $(100 \%)$. It is affected by 3 big reasons. First is the learning continuity. The learner makes listening as a habit. She is accustomed to listen so that recognizing the lyric (listening words) is not as hard as when she never has listening activity. Second, the music rhythm also influenced the listening activity result. Slow song contributes higher score than the beat one. The last is whether the learner ever recognizes the song before. It is seen from the score on the Faded, You are my life, and I promise which are categorized as new song. Beside that, the access on downloading music is easier nowadays so that teenagers are accustomed to finding something new.

The main activity of listening is different. At first, the song is listened 3 times in the 3 meeting. But it seems that the learner gets difficulty, so that it is listened 4 times. First, the teacher gives the full lyric in a good order while listening. The second listening time is in a jumbled card. The $3^{\text {rd }}$ listening for arrangement and the last chance for check her overall work. Beside the amount of listening, the cards are more limited in the $4^{\text {th }}$ until the last meeting. This is because more than 20 
cards are hard to do alone. This is also the important reason of the listening progress.

\section{B. Listening Activities}

Beside listening, there are other different activities before and or after listening as in TABLE II.

TABLE II. ACTIVITIES BEFORE AND AFTER LISTENING

\begin{tabular}{|c|c|c|c|}
\hline \multirow[b]{2}{*}{ Meetings } & \multicolumn{2}{|c|}{ Activities } & \multirow[b]{2}{*}{ Note } \\
\hline & $\begin{array}{c}\text { Main } \\
\text { Listening }\end{array}$ & Additional & \\
\hline $1^{\mathrm{st}}$ & 3 times & Pronunciation & $\begin{array}{c}\text { Learn pronunciation } \\
\text { based on native } \\
\text { voice (new English) }\end{array}$ \\
\hline $2^{\text {nd }}$ & 3 times & Vocabulary & $\begin{array}{c}\text { Recognize and } \\
\text { translate the difficult } \\
\text { words }\end{array}$ \\
\hline $3^{\text {rd }}$ & 3 times & $\begin{array}{l}\text { Discussion on } \\
\text { Cultural view }\end{array}$ & $\begin{array}{l}\text { USA independence } \\
\text { day " } 4^{\text {th }} \text { of July " } \\
\text { (based on the lyrics) }\end{array}$ \\
\hline $4^{\text {th }}$ & 4 times & Pronunciation & $\begin{array}{l}\text { Learn pronunciation } \\
\text { based on native } \\
\text { voice (old English) }\end{array}$ \\
\hline $5^{\text {th }}$ & 4 times & Grammar & $\begin{array}{l}\text { Question words and } \\
\text { the answer }\end{array}$ \\
\hline $6^{\text {th }}$ & 4 times & $\begin{array}{l}\text { Discussion on } \\
\text { religion issue }\end{array}$ & Believe to God \\
\hline $7^{\text {th }}$ & 4 times & $\begin{array}{l}\text { Discussion on } \\
\text { political issue }\end{array}$ & Gaza \\
\hline $8^{\text {th }}$ & 4 times & Writing & $\begin{array}{c}\text { Write down song } \\
\text { review }\end{array}$ \\
\hline $9^{\text {th }}$ & 4 times & $\begin{array}{c}\text { Discussion on } \\
\text { love (parent) } \\
\text { view }\end{array}$ & Love to parents \\
\hline $10^{\text {th }}$ & 4 times & Speaking & $\begin{array}{l}\text { Tell the song's } \\
\text { content orally }\end{array}$ \\
\hline
\end{tabular}

Based on the table above, the additional activities are different in each meeting, although there is the same focus on pronunciation in meeting $1^{\text {st }}$ and $4^{\text {th }}$. The point which makes different is from the singer, Adelle in 2015 and Mariah Carey in 1993. The learner encourages the pronunciation in the different generation. In some meetings, there are discussions about some view/ issue. In this point, the teacher gives questions to be answered based on the topic. These will open and share information both of them. This is the way to avoid the learner's boredom and or create meaningful learning.

\section{Learners' Motivation}

A questionnaire is conducted to know the learner's feeling about the listening activity. There are 5 questions given. Over all, the learner states that she enjoys the learning activity through jumbled lyric card since every have listening class, she has to fill the cloze test listening. This is her first time of her another listening activity. Beside that, she writes that the activity makes her not too feel bored. It also increases her motivation in learning English. In fact, nowadays she likes to listen, write down the song's lyric and also sing the song, such as: Trouble is a friend (Lenka), Flashlight (Jessie J), Someone like you (Adelle) and so on.

\section{CONCLUSION}

Based on the description above, it is concluded that listening activity through jumbled lyrics cards gives big contribution to the learner's learning. First, it increases her listening capability. It is seen from the progress on the $1^{\text {st }}$ until the $10^{\text {th }}$ meeting.Second, the activity makes her have higher motivation and the last is she has meaningful holiday. Both of the reasons are gotten from her questions given from the teacher through questionnaire. In fact, the teacher finds that she likes to listen, write and sing the songs.

\section{References}

[1] H.D. Brown, Language assessment: Principles and classroom practices. White Plains, NY: Pearson Education, 2004.

[2] N. Ruis, Instructional media. Ministry of National Education Indonesia, 2009.

[3] D. Ary, L.C. Jacobs, and C.K. Sorensen, Introduction to Research in Education (Eighth ed.). Belmont, CA: Wadsworth, 2010. 